\title{
Biomarkers of aggressive pituitary adenomas
}

\author{
Ozgur Mete ${ }^{1,2,3}$, Shereen Ezzat ${ }^{3,4,5}$ and Sylvia L Asa ${ }^{1,2,3}$ \\ ${ }^{1}$ Department of Pathology, University Health Network, 200 Elizabeth Street, 11th Floor, Toronto, Ontario, Canada M5G 2C4 \\ ${ }^{2}$ Department of Laboratory Medicine and Pathobiology, University of Toronto, Toronto, Ontario, Canada \\ ${ }^{3}$ Endocrine Oncology Site Group, Princess Margaret Hospital, Toronto, Ontario, Canada \\ ${ }^{4}$ Department of Medicine, University Health Network, Toronto, Ontario, Canada \\ ${ }^{5}$ Department of Medicine, University of Toronto, Toronto, Ontario, Canada \\ (Correspondence should be addressed to O Mete at Department of Pathology, University Health Network; Email: ozgur.mete2@uhn.ca)
}

\begin{abstract}
Pituitary adenomas exhibit a wide range of behaviors. The prediction of aggressive or malignant behavior in pituitary adenomas remains challenging; however, the utility of biomarkers is rapidly evolving. In this review, we discuss potential biomarkers as they relate to aggressive behavior in pituitary adenomas. While detailed histological subtyping remains the best independent predictor of aggressive behavior in the majority of cases, evidence suggests that the additional analyses of FGFR4, MMP, PTTG, Ki-67, p53, and deletions in chromosome 11 may contribute to decisions concerning management of aggressive pituitary adenomas.
\end{abstract}

Journal of Molecular Endocrinology (2012) 49, R69-R78

\section{Introduction}

With modern imaging methods and hormone assays, the diagnosis of pituitary adenomas has increased. These lesions that were known to be common in autopsy studies are thought to occur in almost $20 \%$ of the general population (Ezzat et al. 2004a,b); the increase is not just attributed to better detection of microadenomas but also to macroadenomas (Daly et al. 2006, Fernandez et al. 2010).

These tumors exhibit a wide range of clinical behaviors; some are small and hormonally inactive, others secrete hormones in excess, causing significant morbidity, and some grow rapidly, either by expansion or by infiltration of adjacent tissues (Asa 2011). The terminology 'aggressive' has been largely used synonymously with 'invasive' when evaluating pituitary adenomas. Sometimes, this terminology has been used to define a high risk of recurrence or lack of therapeutic response. Invasive pituitary adenomas that exhibit relatively higher mitotic activity, a MIB-1 labeling index (LI) $>3 \%$, or extensive p53 immunoreactivity are classified as 'atypical adenomas' by the World Health Organization (WHO) (DeLellis et al. 2004). While the WHO 2004 classification has promoted this terminology, in our experience, it does not have any biological superiority to the aggressive histological subtypes as determined by the accurate classification of pituitary adenomas (Mete \& Asa 2012). Some authors classify pituitary adenomas into three pathological groups based on radiological findings: noninvasive, invasive, and aggressive-invasive adenomas (Wierinckx et al. 2007); in their series, aggressiveinvasive adenomas exhibited a Ki-67 index $>1 \%$, mitotic activity more than two per ten high power fields, and p53 expression (Wierinckx et al. 2007).

Detailed and comprehensive morphological studies have identified histological subtypes of pituitary adenomas that are much more complex than simple correlation with clinical behavior (Asa 2011, Mete \& Asa 2012). This classification remains the best independent predictor of aggressive behavior in the majority of pituitary adenomas (Al-Shraim \& Asa 2006). Pituitary adenomas that are associated with aggressive behavior include sparsely granulated somatotroph adenomas, densely granulated lactotroph adenomas, acidophil stem cell adenomas, thyrotroph adenomas, sparsely granulated corticotroph adenomas, Crooke cell adenomas, silent subtype 3 adenomas, and null cell adenomas (Asa \& Ezzat 2009, Asa 2011, Mete \& Asa 2012). These aggressive adenomas are usually invasive macroadenomas radiographically. Some adenomas, such as silent subtype 3 adenomas and acidophil stem cell adenomas, reveal characteristic preferential downward invasive growth with significant bone invasion and parasellar extension rather than 
suprasellar expansion (Asa 2011, Mete \& Asa 2012), and complete curative resection cannot be achieved in the majority of these cases due to their invasive nature. Importantly, other less aggressive adenomas can sometimes be invasive; for example, sparsely granulated lactotroph adenomas in men often present as large macroadenomas that exhibit sinonasal invasion (Asa \& Ezzat 2009, Asa 2011).

The therapy of aggressive pituitary adenomas is challenging. When surgery and medical therapy fail, radiotherapy becomes the treatment of choice. Conventional chemotherapy is largely ineffective but recent case reports using temozolomide have provided early encouraging results (Colao et al. 2011, Mete \& Asa 2012).

\section{Biomarkers of aggressive behavior in pituitary adenomas}

Several biological markers have been investigated in pituitary tumors. They include chromosomal alterations and microRNAs (miRNAs), proliferation markers, oncogenes, tumor suppressor genes, growth factors and their receptors, and factors related to angiogenesis or cell adhesion. No single biomarker has been found to independently predict aggressive behavior in pituitary neoplasms (Thapar et al. 1996b, Zhao et al. 1999, McCabe et al. 2002, Ezzat et al. 2004a,b, Asa et al. 2007, Gong et al. 2008, Wang et al. 2008, Asa \& Ezzat 2009, Salehi et al. 2009, 2010, Asa 2011, Sivapragasa et al. 2011, Wierinckx et al. 2011, Cornelius et al. 2012). In this review, we focus on biomarkers that appear to correlate with aggressive behavior in pituitary adenomas.

\section{Fibroblast growth factor receptor 4}

Fibroblast growth factors (FGFs) and their receptors (FGFRs) are a family of ligands and receptors that regulate development, growth, differentiation, migration, and angiogenesis (Ezzat et al. 2004a,b). Basic FGF (bFGF; FGF2) was originally described in bovine pituitary folliculostellate cells that regulate pituitary hormone secretion (Ferrara et al. 1987, Gospodarowicz et al. 1987). Deletion of FGF10 or its receptor, the FGFR2IIIb isoform, results in failure of primordial pituitary development (De Moerlooze et al. 2000). While varying levels of FGF mRNA expression have been documented in pituitary adenomas, the highest FGF mRNA and blood levels are associated with the most aggressive pituitary tumors (Ezzat et al. 1995a,b).

The 23 FGF ligands signal through four transmembrane tyrosine kinase receptors encoded by independent genes that each generates multiple isoforms. Each prototypic FGFR contains three Ig-like extracellular domains, a single transmembrane domain, a split tyrosine kinase cytoplasmic domain, and a $\mathrm{COOH}$-terminal tail that typically contains tyrosines that are phosphorylated upon ligand binding and recruit intracellular signaling proteins (Givol \& Yayon 1992, Abbass et al. 1997, Qian et al. 2004). While some FGFs can signal through multiple receptors, the majority have specific affinity for selected receptor isoforms.

FGFRs are expressed in a variety of neoplasms including breast carcinomas, ovarian carcinomas, gastric carcinomas, colorectal carcinomas, prostate carcinomas, pancreatic carcinomas, melanomas, and glial neoplasms (Jaakkola et al. 1993, Morrison et al. 1994, Ohta et al. 1995, Ahmed et al. 1997, Yoshimura et al. 1998, Giri et al. 1999, Shin et al. 2000, Yamada et al. 2002, Henriksson et al. 2011). A single nucleotide polymorphism (SNP) in FGFR4, in which arginine is substituted for glycine at codon 388 in the transmembrane domain (FGFR4-G388R), occurs in up to $50 \%$ of the population; the arginine allele has been associated with advanced and treatment-resistant breast carcinoma, colorectal carcinoma, prostate carcinoma, sarcomas, and head and neck carcinomas (Bange et al. 2002, Morimoto et al. 2003, da Costa Andrade et al. 2007, Frullanti et al. 2011). The FGFR4-R388 allele has also recently been linked with mitochondrial STAT3 serine phosphorylation that facilitates pituitary growth hormone (GH) cell tumorigenesis (Tateno et al. 2011).

Pituitary adenomas have altered FGFR subtype and isoform expression (Abbass et al. 1997). The normal human pituitary expresses mRNAs for FGFR1, 2, and 3, including both Ig-like extracellular domains as well as transmembrane and kinase domains; by contrast, transcripts of only the first Ig-like domain of FGFR4 were found in the normal gland (Abbass et al. 1997). Pituitary adenomas show two major alterations: loss of FGFR2, with resultant upregulation of MAGEA3 (Zhu et al. 2008), and an N-terminally truncated cytoplasmic isoform of FGFR4, known as pituitary tumor derived (ptd-FGFR4) (Ezzat et al. 2002, Qian et al. 2004).

Whereas WT FGFR4 (FGFR4-G388) is a $110 \mathrm{kDa}$ membrane-anchored protein that maintains affinity for the extracellular matrix of normal adenohypophyseal cells, ptd-FGFR4 is a $65 \mathrm{kDa}$ cytoplasmic protein that is constitutively activated by phosphorylation on tyrosine residues. Intact FGFR4 is known to interact with neural cell adhesion molecule (NCAM) and $\mathrm{N}$-cadherin (Cavallaro et al. 2001). The altered expression of FGFR4, thought to be due to Ikaros-induced silencing of the $5^{\prime}$-FGFR4 promoter (Yu et al. 2002, Ezzat et al. 2003) and unmasking of a cryptic intronic promoter (Yu et al. 2003), interferes with the triprotein complex, displacing $\mathrm{N}$-cadherin into the cytoplasm (Ezzat et al. 2004a,b). Expression of ptd-FGFR4 induces invasive growth of pituitary tumor cells in vivo with marked loss of membranous $\mathrm{N}$-cadherin expression 

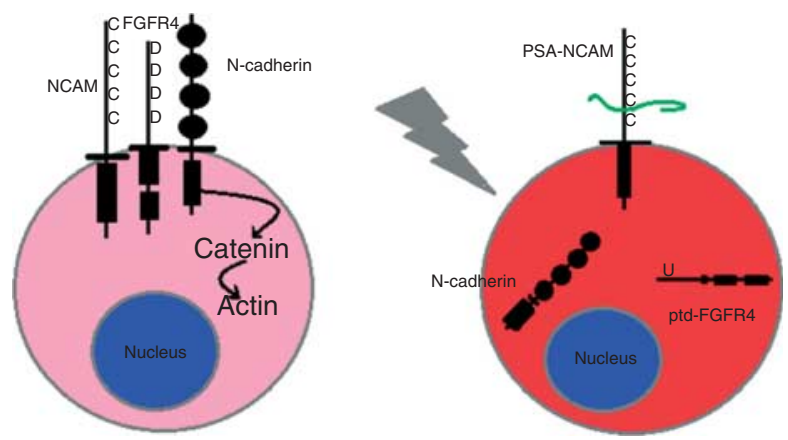

Figure 1 The integrity of FGFR4/NCAM/N-cadherin/ $\beta$-catenin complexes is necessary to maintain normal neuroendocrine cell phenotype and interactions with the extracellular matrix. Intact NCAM association with FGFR4 maintains $\mathrm{N}$-cadherin at the cell membrane that links $\beta$-catenin to the cell surface. Altered protein interactions induced by cytoplasmic ptd-FGFR4 and/or the polysialated form of NCAM (PSA-NCAM) result in disruption of $\mathrm{N}$-cadherin residence at the cell membrane and loss of $\beta$-cateninmediated cytoskeletal integrity. Expression of ptd-FGFR4 induces invasive growth of pituitary tumor cells in vivo with marked loss of membranous $\mathrm{N}$-cadherin expression, and the PSA-NCAM also correlates with pituitary tumor growth and invasiveness (Adapted from Asa SL \& Ezzat S 2009 The pathogenesis of pituitary tumors. Annual Review of Pathology 4 97-126.).

(Ezzat et al. 2004a,b, Morita et al. 2008; Figs 1 and 2). The polysialated form of NCAM (PSA-NCAM) also correlates with pituitary tumor growth and invasiveness (Daniel et al. 2000). Evidence suggests that the signaling properties of $\mathrm{N}$-cadherin, with particular emphasis on its cross talk with cell surface partners such as FGFR4 and NCAM, are important in pituitary tumorigenesis (Ezzat et al. 2004a,b, 2006, Asa \& Ezzat 2009). Intact NCAM association with FGFR4 maintains N-cadherin at the cell membrane that links $\beta$-catenin to the cell surface (Fig. 1). The integrity of FGFR4/NCAM/N-cadherin/ $\beta$-catenin complexes is necessary to maintain normal neuroendocrine cell phenotype and interactions with the extracellular matrix (Ezzat et al. 2004a,b, 2006, Asa \& Ezzat 2009). Altered protein interactions induced by cytoplasmic ptd-FGFR4 and/or PSA-NCAM (Fig. 1) result in disruption of $\mathrm{N}$-cadherin residence at the cell membrane and loss of $\beta$-catenin-mediated cytoskeletal integrity (Ezzat et al. 2006, Asa \& Ezzat 2009). Reduced $\beta$-catenin expression is a recognized feature of invasive pituitary adenomas (Asa \& Ezzat 2005). Furthermore, pharmacological inhibition of WT FGFR4 results in N-cadherin displacement and impaired cell-matrix adhesiveness, whereas pharmacological inhibition of ptd-FGFR4 can restore acinar architecture (Ezzat et al. 2006).

\section{Matrix metalloproteinases}

Matrix metalloproteinases (MMPs) are a family of single-chain zinc-containing proteolytic enzymes that regulate the extracellular matrix in both physiological and pathological conditions including neoplasia. Eight different classes that encompass at least 24 functional types of MMPs have been described (Arakaki et al. 2009). They cleave extracellular matrix molecules including collagens, laminin, fibronectin, vitronectin, and proteoglycans. While the expression of MMP1, MMP2, MMP7, and MMP14 is regulated by transcription factors such as SMAD interacting protein-1 (SIP1) and Snail, various polymorphisms in $M M P$ promoters and oncogenic signal transduction can induce transcription of MMPs (Miyoshi et al. 2004, Arakaki et al. 2009, Ota et al. 2009, González-Arriaga et al. 2012). Invasive tumor cells secrete MMPs, and mesenchymal cells, especially fibroblasts, represent an important source of these enzymes in the tumor microenvironment.

MMP1 is one of the most common interstitial collagenases and degrades mainly type I collagen (Arakaki et al. 2009). MMP1 expression has been linked to a poor prognosis in several cancers including oral carcinoma (Nishizawa et al. 2007, Shimizu et al. 2008), nasopharyngeal carcinoma (Nasr et al. 2007), and colorectal cancer (Woo et al. 2007). The MMP1 gene is located on chromosome 11q22 (Arakaki et al. 2009). Both the proximal and distal regions of the MMP1 promoter recognize the Jun/Fos dimer accompanied by the polyomavirus enhancer A binding protein 3 (PEA3), which in turn binds members of the electron transport system (ETS) transcription factor family (Wasylyk et al. 1991, Sharrocks et al. 1997). Higher levels of ETS transcription factors induce MMP1 expression, thereby increasing degradation of the extracellular matrix to promote motility or invasion of tumor cells (Buttice et al. 1996, Westermarck et al. 1997). A SNP in the MMP1 gene promoter, which inserts a guanine $(\mathrm{G})$ at position 1607 (Arakaki et al. 2009), gives rise to a new ETS recognition site ( $5^{\prime}$-GGA-3 $\left.{ }^{\prime}\right)$
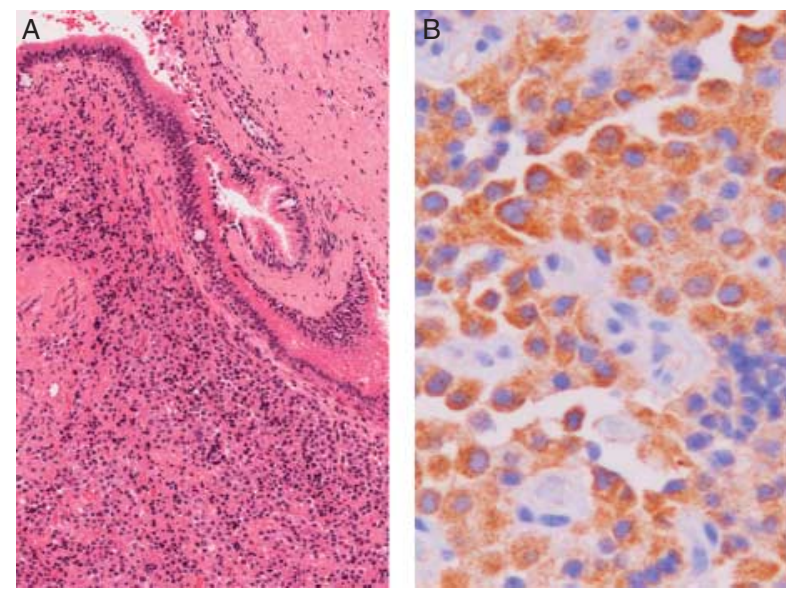

Figure 2 A gonadotroph adenoma that shows extensive sinonasal mucosal invasion (A) exhibits strong cytoplasmic positivity for FGFR4, consistent with ptd-FGFR4 (B). 
(Rutter et al. 1998). Altas et al. (2010) investigated the impact of this polymorphism in pituitary adenomas and demonstrated that $90 \%$ of invasive pituitary adenomas occur in patients who are homozygous for this MMP1 SNP.

MMP9 is located on chromosome 20q12-13 and degrades collagens (types IV, V, and X), elastin, gelatin, fibronectin, and proteoglycan-link protein (Chakraborti et al. 2003). MMP9 is activated by several factors including other MMPs such as MMP2, MMP3, and MMP13 (Chakraborti et al. 2003). Its secretion appears at an early stage of tumor cell migration (Paez-Pereda et al. 2005). Both MMP2 and MMP9 are widely expressed by endothelial cells and stromal cells. Their expression has been investigated in several malignancies including breast and lung cancers. MMP9 expression is significantly higher in invasive pituitary adenomas (Kawamoto et al. 1996, Liu et al. 2005, Hussaini et al. 2007, Gong et al. 2008) and MMP2 is also elevated ( $\mathrm{Liu}$ et al. 2005). Moreover, there may be a correlation between activation of protein kinase $\mathrm{C}$ (PKC) and increased levels of MMP9, which can be antagonized by PKC inhibitors (Hussaini et al. 2007).

The FGFR4 SNP has also been linked to MMP expression (Sugiyama et al. 2010). MT1-MMP (MMP14) is known to regulate tissue remodeling and cell invasiveness and serves as an activator for secreted MMPs, especially MMP2 and MMP13 (Page-McCaw et al. 2007, Rowe \& Weiss 2009). While FGFR4-G388 downregulates MT1-MMP, the FGFR4-R388 variant induces MT1-MMP activity and collagen invasion. Although the role of FGFR4-R388 with respect to MMP14 has not been largely investigated in invasive pituitary adenomas, the association of increased levels of MMP9 and MMP2 in invasive adenomas may suggest a potential link to the FGFR4 polymorphism. Further investigations are warranted to clarify the interactions between these biomarkers.

\section{GH receptor mutations}

Hypothalamic adenohypophysiotrophic hormones regulate their target cells through their receptors in complex feedback mechanisms (Asa 1991). In somatotrophs, GHRH is known to stimulate GH secretion and somatotroph proliferation through its receptor that binds the Gs $\alpha$ to increase cAMP levels. Densely granulated somatotroph adenomas have high cAMP levels, often due to somatic activating gsp mutations in the gene encoding Gs $\alpha$. These tumors are usually responsive to somatostatin analogs that typically activate inhibitory $\mathrm{G}$ proteins, reducing cAMP levels (Bhayana et al. 2005, Asa \& Ezzat 2009, Asa 2011, Mete \& Asa 2012). However, the potential role of GH in autoregulation was not appreciated until it was shown that mice with GH receptor (GHR) disruption develop somatotroph hyperplasia (Asa et al. 2000). Germline mutations in exon 4 of the GHR result in Laron-type dwarfism with GH resistance (Putzolu et al. 1997, Chen et al. 2003, Shevah et al. 2004). Sparsely granulated adenomas, which are by definition aggressive GH-producing adenomas, are thought to lack the high levels of cAMP that predict a response to somatostatin analogs (Ezzat et al. 1995a,b, Bhayana et al. 2005); instead, they have altered STAT signaling that, in some cases, has been attributed to a somatic GHR mutation resulting in a histidine-to-leucine substitution in the extracellular domain in exon 4, codon 49. This mutation impairs glycosylation-mediated receptor processing and signaling (Asa et al. 2007, Mete \& Asa 2012). Altered GHR signaling is also associated with a morphological change resulting in the formation of paranuclear keratin aggresomes (Fig. 3), also known as 'fibrous bodies' (Asa et al. 2007). This marker of altered GH autoregulation allows pathologists to distinguish sparsely granulated somatotroph adenomas from their densely granulated counterparts using immunohistochemistry for low-molecular-weight keratin (CAM5.2) (Fig. 4). The discrimination of this entity is not only of prognostic interest, as sparsely granulated somatotroph adenomas are known to be more aggressive than their densely granulated counterparts, but also has major implications for treatment decisions, as Pegvisomant, a GHR antagonist, is used in patients with sparsely

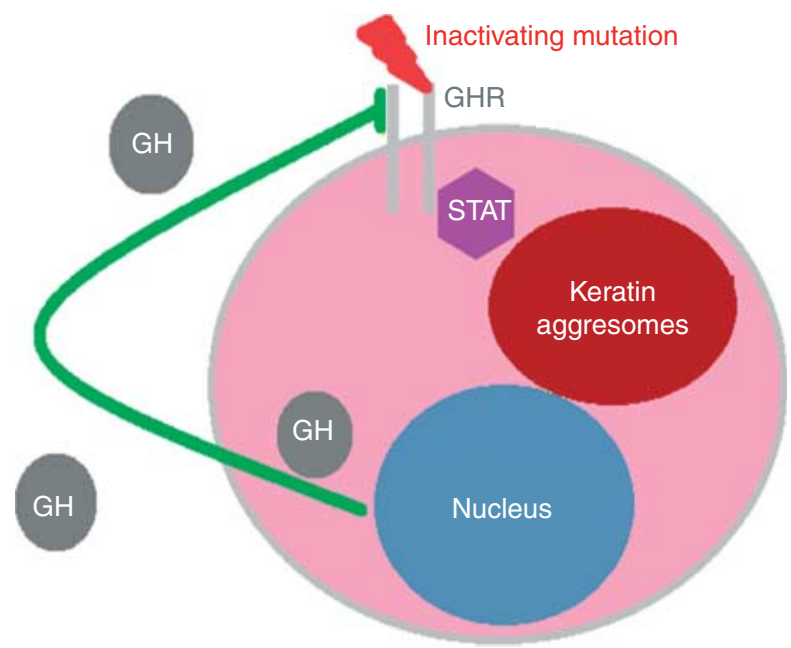

Figure 3 Sparsely granulated adenomas, which are by definition aggressive $\mathrm{GH}$-producing adenomas, are thought to lack the high levels of cAMP that predict a response to somatostatin analogs; instead, they have altered STAT signaling that in some cases has been attributed to a somatic GHR mutation resulting in a histidineto-leucine substitution in the extracellular domain in exon 4, codon 49. Altered GHR signaling is associated with a morphological change resulting in the formation of paranuclear keratin aggresomes, also known as 'fibrous bodies' (Adapted from Asa SL \& Ezzat S 2009 The pathogenesis of pituitary tumors. Annual Review of Pathology 4 97-126.). 

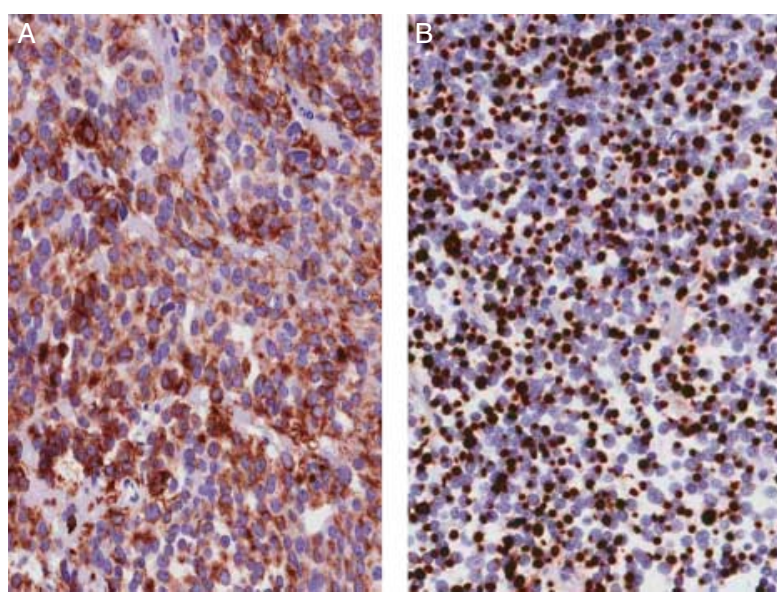

Figure 4 Low-molecular-weight keratin (CAM5.2) immunohistochemistry serves as a diagnostic and prognostic tool for pathologists to distinguish densely granulated somatotroph adenomas (A) from sparsely granulated somatotroph adenomas that contain fibrous bodies (B).

granulated somatotroph adenomas that do not respond to somatostatin analogs (Bhayana et al. 2005, Asa et al. 2007, Asa 2011, Mete \& Asa 2012).

\section{Loss of chromosome 11p and/or 11q}

Genomic imbalance has been reported to occur frequently in pituitary tumors (Weil et al. 1998, Pack et al. 2000, 2005). Allelic deletions at 11q13, 13q12-14, $10 \mathrm{q}$, and $1 \mathrm{p}$ have been reported in invasive pituitary adenomas (Bates et al. 1997). Loss of the 11p region has been described in several familial and sporadic neoplasms including those arising from breast, ovary, thyroid, and bladder (Kiechle-Schwarz et al. 1993, Voorter et al. 1996, Kitamura et al. 2000). Some of these studies also highlighted that loss of $11 p$ correlates with tumor progression and metastasis. In addition to a previously reported panel of seven genes (CRMP1, ADAMTS6, PTTG1, CCNB1, AURKB, ASK (DBF4), and $C E N P E)$ that correlate with recurrence or progression in PRL-producing tumors (Raverot et al. 2010), Wierinckx et al. (2011) highlighted the impact of deregulation of five genes on $11 \mathrm{p}, C D 44, D G K Z$, TSG101, GTF2H1, and HTATIP2, that are potentially responsible for aggressive and malignant behavior in PRL-producing tumors. Based on their results, Wierinckx et al. (2011) proposed a model for progression wherein genomic instability of $11 \mathrm{q}$ in association with $11 \mathrm{p}$ loss can be responsible for an aggressive and malignant phenotype in PRL-producing tumors. In fact, $11 \mathrm{q}$ is implicated in somatotroph and lactotroph adenomas; both the aryl hydrocarbon receptor interacting protein and multiple endocrine neoplasia (MEN1) genes are located at 11q13 (Tahir et al. 2010, Newey \& Thakker 2011).

\section{Pituitary tumor transforming gene}

Pituitary tumor transforming gene $(P T T G)$ is a member of the securin family, which regulates sister chromatid separation during mitosis (Zou et al. 1999). PTTG was initially isolated and described in rat pituitary GH4 cells (Pei \& Melmed 1997). The human PTTG family consists of at least three genes: PTTG1, PTTG2, and $P T T G 3$. Evidence suggests tissue-specific expression of the three $P T T G$ genes and potential roles for each of them in tumorigenesis, cell transformation, DNA repair, angiogenesis, and gene regulation (Salehi et al. 2008). As securins are required for cell division, it is not surprising that loss of PTTG suppresses cell proliferation, diminishing the development of pituitary tumors in Rb-deficient animals (Chesnokova et al. 2005). It is also expected that PTTG expression is increased in tumors of all types. It has been shown that PTTG upregulates vascular endothelial growth factor and bFGF expression, both of which are elevated in pituitary tumors (Ishikawa et al. 2001, McCabe et al. 2002).

Hunter et al. (2003) showed statistically higher levels of $P T T G$ mRNA in somatotroph adenomas compared with nonfunctioning tumors. However, no statistical differences were observed when comparing corticotroph, lactotroph, and somatotroph adenomas. In some series, PTTG expression was found to be higher in hormone-secreting invasive pituitary adenomas than their noninvasive counterparts (Pei \& Melmed 1997, Zhang et al. 1999). Filippella et al. (2006) reported that a PTTG/Ki-67 score higher than $2.9 \%$ predicts a biologically aggressive behavior in pituitary adenomas. PTTG expression is also high in malignant rat PRL-producing tumors (Wierinckx et al. 2007). However, as is the case for other markers of proliferation, such as Ki-67 and PCNA, it remains to be seen whether these results provide valuable information that can be used for clinical management.

\section{Ki-67}

Nuclear Ki-67 (identified with the MIB-1 antibody) is a marker of cell division that is usually counted to determine a proliferation index in neoplasms (Fig. 5). The Ki-67 LI is of prognostic significance in the assessment of neuroendocrine tumors, especially those originating from the gastrointestinal tract and pancreas (Bosman et al. 2010). Ki-67 has also been studied extensively in pituitary tumors. The Ki-67 LI has been reported to vary from $<1 \%$ to as high as $23 \%$ in a series (Salehi et al. 2009). A significant association of Ki-67 LI with invasion was found in several studies (Landolt et al. 1987, Daita \& Yonemasu 1996, Thapar et al. 1996a, Zhao et al. 1999, Iuchi et al. 2000, Jaffrain-Rea et al. 2002, Wolfsberger et al. 2004). Thapar et al. (1996a) established a threshold LI of $3 \%$ to 


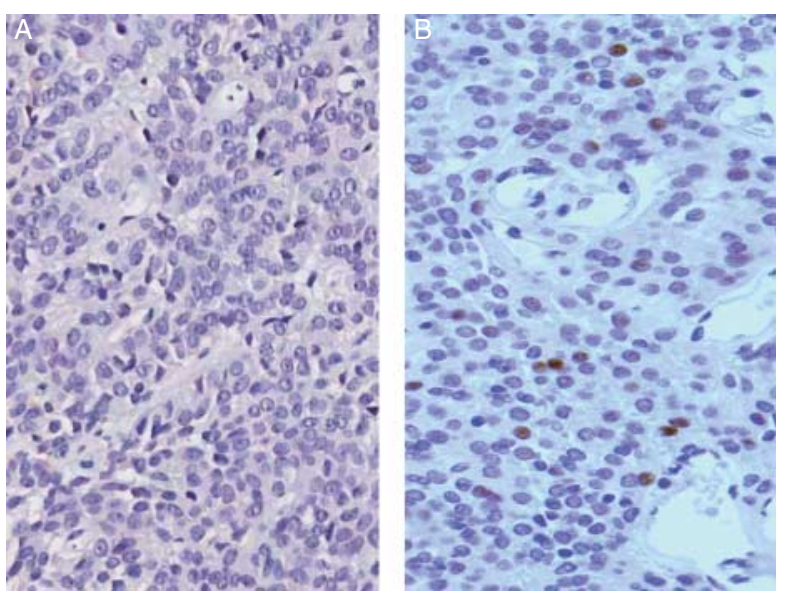

Figure 5 Nuclear Ki-67 (identified with the MIB-1 antibody) expression can be variable in pituitary tumors; some pituitary adenomas can exhibit $<1 \%$ positive cells $(A)$, while others have higher labeling index as illustrated in this lactotroph adenoma (B).

distinguish invasive from noninvasive adenomas with $97 \%$ specificity and $73 \%$ sensitivity, and this was associated with positive and negative predictive values of $96 \%$ and $80 \%$ respectively. With some exceptions, invasive pituitary tumors exhibit significantly higher growth fractions (Thapar et al. 1996a). Pizarro et al. (2004) showed that invasive pituitary adenomas had a significantly higher Ki-67 index $(2 \cdot 01 \pm 3 \cdot 15 \%)$ than macroadenomas $(1 \cdot 12 \pm 1 \cdot 87 \%)$; however, the $\mathrm{Ki}-67$ index was not significantly different in the subgroup of adenomas with invasion of the cavernous sinus compared with groups with other types of invasion. Nevertheless, the ability of the Ki-67 index to predict tumor invasiveness is somewhat controversial as others have found no difference in $\mathrm{Ki}-67$ expression in invasive pituitary adenomas (Yonezawa et al. 1997, Lath et al. 2001, Paek et al. 2005, Pan et al. 2005, Wierinckx et al. 2007).

\section{p53}

p53 is a tumor suppressor protein encoded by the TP53 gene. It plays an important role in cell proliferation, apoptosis, and genomic stability. p53 expression has been linked to aggressive tumor behavior in pituitary tumors. Thapar et al. (1996b) demonstrated that noninvasive and invasive adenomas and pituitary carcinomas revealed p53 expression in $0 \%, 15 \cdot 2 \%$, and $100 \%$ of cases respectively. While some studies have suggested that p53 correlates with local relapse in pituitary adenomas (Ozer et al. 2003), 'aggressive-invasive' PRL-producing tumors were associated with higher p53 expression (Wierinckx et al. 2007). Again, similar to Ki-67 LI, other papers did not observe this significant correlation with invasive growth (Suliman et al. 2001, Hentschel et al. 2003, Scheithauer et al. 2006). These conflicting results suggest that p53 is not an independent prognostic factor to determine the aggressive behavior of pituitary tumors.

\section{miRNAs}

miRNAs are small endogenous noncoding RNAs that regulate gene expression at the posttranscriptional level by direct cleavage of a mRNA or by inhibition of protein synthesis; they can also act as tumor suppressor genes or oncogenes (Sivapragasam et al. 2011). Aberrant miRNA expression has been linked to neoplasia in the pituitary gland. Stilling et al. (2010) reported differential expression of miR-122 in corticotroph adenomas compared with corticotroph carcinomas. Underexpression of miR-145, miR-21, miR-141, let-7a, miR-150, miR-15a, miR-16, and miR-145 has been reported in ACTH-producing adenomas. Although miRNA expression did not correlate with tumor size in one study, lower miR-141 expression correlated with postoperative remission in patients with corticotroph adenomas (Amaral et al. 2009). Reduced expression of miR-15a and miR-16-1 has been linked to tumor size in GH- and PRL-producing adenomas (Bottoni et al. 2004); however, this was not the case in corticotroph adenomas (Amaral et al. 2009).

Recently, a significant link between HMGA 2 oncogene and let-7 miRNA has been shown in pituitary tumorigenesis (Qian et al. 2009). In this series, high levels of expression of HMGA2 correlated with the extent of invasion, tumor size, and the $\mathrm{Ki}-67$ proliferation index in pituitary adenomas. In addition, loss or reduction of let-7 expression contributes to increased HMGA2 protein expression in pituitary adenomas. Higher expression of HMGA2 and lower let-7 expression were also noted in invasive pituitary adenomas (Qian et al. 2009).

\section{Conclusion}

Despite emerging evidence, there is still little consensus about what constitutes an aggressive pituitary adenoma. The diagnosis of pituitary carcinoma is still restricted to adenohypophyseal proliferations that exhibit cerebrospinal and/or systemic metastasis (DeLellis et al. 2004, Asa 2011, Mete \& Asa 2012). Thus, no morphological criteria appear to distinguish aggressive adenomas from carcinomas. Although many of the molecular events underlying pituitary tumorigenesis have been elucidated, reliable biological prognostic markers remain to be identified. We propose that detailed and comprehensive histological subtyping should be integrated with a panel of biomarkers. Of these, FGFR4, MMP, PTTG, Ki67 LI, p53, miRNA profile, and deletions in chromosome 11 p currently represent promising candidates with the potential to guide the management of patients with aggressive pituitary adenomas. 


\section{Declaration of interest}

The authors declare that there is no conflict of interest that could be perceived as prejudicing the impartiality of the research reported.

\section{Funding}

This work was supported in part by grants from the Canadian Institutes of Health Research.

\section{References}

Abbass SA, Asa SL \& Ezzat S 1997 Altered expression of fibroblast growth factor receptors in human pituitary adenomas. Journal of Clinical Endocrinology and Metabolism 82 1160-1166. (doi:10.1210/ jc.82.4.1160)

Ahmed NU, Ueda M, Ito A, Ohashi A, Funasaka Y \& Ichihashi M 1997 Expression of fibroblast growth factor receptors in naevus-cell naevus and malignant melanoma. Melanoma Research 7 299-305. (doi:10.1097/00008390-199708000-00004)

Al-Shraim M \& Asa SL 2006 The 2004 World Health Organization classification of pituitary tumors: what is new? Acta Neuropathologica 111 1-7. (doi:10.1007/s00401-005-1093-6)

Altaş M, Bayrak OF, Ayan E, Bolukbasi F, Silav G, Coskun KK, Culha M, Sahin F, Sevli S \& Elmaci I 2010 The effect of polymorphisms in the promoter region of the MMP-1 gene on the occurrence and invasiveness of hypophyseal adenoma. Acta Neurochirurgica 152 1611-1617. (doi:10.1007/s00701-010-0671-0)

Amaral FC, Torres N, Saggioro F, Neder L, Machado HR, Silva WA Jr, Moreira AC \& Castro M 2009 MicroRNAs differentially expressed in ACTH-secreting pituitary tumors. Journal of Clinical Endocrinology and Metabolism 94 320-323. (doi:10.1210/jc.2008-1451)

Arakaki PA, Marques MR \& Santos MC 2009 MMP-1 polymorphism and its relationship to pathological processes. Journal of Biosciences 34 313-320. (doi:10.1007/s12038-009-0035-1)

Asa SL 1991 The role of hypothalamic hormones in the pathogenesis of pituitary adenomas. Pathology, Research and Practice 187 581-583. (doi:10.1016/S0344-0338(11)80149-4)

Asa SL 2011 Tumors of the pituitary gland. Fascicle 15, 4th Series. In The Atlas of Tumor Pathology. Washington DC: Armed Forces Institute of Pathology.

Asa SL \& Ezzat S 2005 Genetics and proteomics of pituitary tumors. Endocrine 28 43-47. (doi:10.1385/ENDO:28:1:043)

Asa SL \& Ezzat S 2009 The pathogenesis of pituitary tumors. Annual Review of Pathology 4 97-126. (doi:10.1146/annurev.pathol.4. 110807.092259)

Asa SL, Coschigano KT, Bellush L, Kopchick IJ \& Ezzat S 2000 Evidence for growth hormone $(\mathrm{GH})$ autoregulation in pituitary somatotrophs in $\mathrm{GH}$ antagonist-transgenic mice and $\mathrm{GH}$ receptordeficient mice. American Journal of Pathology 156 1009-1015. (doi:10.1016/S0002-9440(10)64968-1)

Asa SL, Digiovanni R, Jiang J, Ward ML, Loesch K, Yamada S, Sano T, Yoshimoto K, Frank SJ \& Ezzat S 2007 A growth hormone receptor mutation impairs growth hormone autofeedback signaling in pituitary tumors. Cancer Research 67 7505-7511. (doi:10.1158/00085472.CAN-07-0219)

Bange J, Prechtl D, Cheburkin Y, Specht K, Harbeck N, Schmitt M, Knyazeva T, Muller S, Gartner S, Sures I et al. 2002 Cancer progression and tumor cell motility are associated with the FGFR4 $\operatorname{Arg}(388)$ allele. Cancer Research 62 840-847.

Bates AS, Farrell WE, Bicknell JE, McNicol AM, Talbot JA, Broome JC, Perrett CW, Thakker RV \& Clayton RN 1997 Genetic instability in pituitary adenomas reflects aggressive biological activity and has potential value as a prognostic marker. Journal of Clinical Endocrinology and Metabolism 82 818-824. (doi:10.1210/jc.82.3.818)
Bhayana S, Booth GL, Asa SL, Kovacs K \& Ezzat S 2005 The implication of somatotroph adenoma phenotype to somatostatin analog responsiveness in acromegaly. Journal of Clinical Endocrinology and Metabolism 90 6290-6295. (doi:10.1210/jc.2005-0998)

Bosman FT, Carneiro F, Hruban RH \& Theise ND (eds) 2010 WHO classification of tumours of the digestive system. Lyon: IARC.

Bottoni A, Piccin D, Tagliati F, Luchin A, Zatelli MC \& degli Uberti EC 2004 miR-15a and miR-16-1 down-regulation in pituitary adenomas. Journal of Cellular Physiology 204 280-285. (doi:10.1002/jcp.20282)

Buttice G, Duterque-Coquillaud M, Basuyaux JP, Carrere S, Kurkinen M \& Stehelin D 1996 Erg, an Ets-family member, differentially regulates human collagenase1 (MMP-1) and stromelysin1 (MMP3) gene expression by physically interacting with the Fos/Jun complex. Oncogene 13 2297-2306.

Cavallaro U, Niedermeyer J, Fuxa M \& Christofori G 2001 N-CAM modulates tumour-cell adhesion to matrix by inducing FGFreceptor signalling. Nature Cell Biology 3 650-657. (doi:10.1038/ 35083041)

Chakraborti S, Mandal M, Das S, Mandal A \& Chakraborti T 2003 Regulation of matrix metalloproteinases: an overview. Molecular and Cellular Biochemistry 253 269-285. (doi:10.1023/A:1026028303196)

Chen X, Song F, Dai Y, Bao X \& Jin Y 2003 A novel mutation of the growth hormone receptor gene (GHR) in a Chinese girl with Laron syndrome. Journal of Pediatric Endocrinology $\mathcal{E}$ Metabolism 16 1183-1189. (doi:10.1515/JPEM.2003.16.8.1183)

Chesnokova V, Kovacs K, Castro AV, Zonis S \& Melmed S 2005 Pituitary hypoplasia in $\mathrm{Pttg}-/-$ mice is protective for $\mathrm{Rb}+/-$ pituitary tumorigenesis. Molecular Endocrinology 19 2371-2379. (doi:10.1210/ me.2005-0137)

Colao A, Grasso LF, Pivonello R \& Lombardi G 2011 Therapy of aggressive pituitary tumors. Expert Opinion on Pharmacotherapy 12 1561-1570. (doi:10.1517/14656566.2011.568478)

Cornelius A, Cortet-Rudelli C, Assaker R, Kerdraon O, Gevaert MH, Prévot V, Lassalle P, Trouillas J, Delehedde M \& Maurage CA 2012 Endothelial expression of endocan is strongly associated with tumor progression in pituitary adenoma. Brain Pathology. In press. (doi:10.1111/j.1750-3639.2012.00578.x)

da Costa Andrade VC, Parise O Jr, Hors CP, de Melo Martins PC, Silva AP \& Garicochea B 2007 The fibroblast growth factor receptor 4 (FGFR4) Arg388 allele correlates with survival in head and neck squamous cell carcinoma. Experimental and Molecular Pathology 82 53-57. (doi:10.1016/j.yexmp.2006.05.003)

Daita G \& Yonemasu Y 1996 Dural invasion and proliferative potential of pituitary adenomas. Neurologia Medico-Chirurgica 36 211-214. (doi:10.2176/nmc.36.211)

Daly AF, Rixhon M, Adam C, Dempegioti A, Tichomirowa MA \& Beckers A 2006 High prevalence of pituitary adenomas: a crosssectional study in the province of Liege, Belgium. Journal of Clinical Endocrinology and Metabolism 91 4769-4775. (doi:10.1210/jc. 2006-1668)

Daniel L, Trouillas J, Renaud W, Chevallier P, Gouvernet J, Rougon G \& Figarella-Branger D 2000 Polysialylated-neural cell adhesion molecule expression in rat pituitary transplantable tumors (spontaneous mammotropic transplantable tumor in Wistar-Furth rats) is related to growth rate and malignancy. Cancer Research 60 80-85.

DeLellis RA, Lloyd RV, Heitz PU \& Eng C, eds 2004 World Health Organization Classification of Tumours. Pathology and Genetics of Tumours of Endocrine Organs. Lyon: IARC Press.

De Moerlooze L, Spencer-Dene B, Revest J, Hajihosseini M, Rosewell I \& Dickson C 2000 An important role for the IIIb isoform of fibroblast growth factor receptor 2 (FGFR2) in mesenchymalepithelial signalling during mouse organogenesis. Development 127 483-492.

Ezzat S, Kontogeorgos G, Redelmeier DA, Horvath E, Harris AG \& Kovacs K 1995 a In vivo responsiveness of morphological variants of growth hormone-producing pituitary adenomas to octreotide. European Journal of Endocrinology 133 686-690. (doi:10.1530/eje.0. 1330686) 
Ezzat S, Smyth HS, Ramyar L \& Asa SL $1995 b$ Heterogenous in vivo and in vitro expression of basic fibroblast growth factor by human pituitary adenomas. Journal of Clinical Endocrinology and Metabolism 80 878-884. (doi:10.1210/jc.80.3.878)

Ezzat S, Zheng L, Zhu XF, Wu GE \& Asa SL 2002 Targeted expression of a human pituitary tumor-derived isoform of FGF receptor-4 recapitulates pituitary tumorigenesis. Journal of Clinical Investigation 109 69-78.

Ezzat S, Yu S \& Asa SL 2003 Ikaros isoforms in human pituitary tumors: distinct localization, histone acetylation, and activation of the $5^{\prime}$ fibroblast growth factor receptor-4 promoter. American Journal of Pathology 163 1177-1184. (doi:10.1016/S0002-9440(10)63477-3)

Ezzat S, Asa SL, Couldwell WT, Barr CE, Dodge WE, Vance ML \& McCutcheon IE 2004 $a$ The prevalence of pituitary adenomas: a systematic review. Cancer 101 613-619. (doi:10.1002/cncr.20412)

Ezzat S, Zheng L \& Asa SL $2004 b$ Pituitary tumor-derived fibroblast growth factor receptor 4 isoform disrupts neural cell-adhesion molecule/N-cadherin signaling to diminish cell adhesiveness: a mechanism underlying pituitary neoplasia. Molecular Endocrinology 18 2543-2552. (doi:10.1210/me.2004-0182)

Ezzat S, Zheng L, Winer D \& Asa SL 2006 Targeting N-cadherin through fibroblast growth factor receptor-4: distinct pathogenetic and therapeutic implications. Molecular Endocrinology 20 2965-2975. (doi:10.1210/me.2006-0223)

Fernandez A, Karavitaki N \& Wass JA 2010 Prevalence of pituitary adenomas: a community-based, cross-sectional study in Banbury (Oxfordshire, UK). Clinical Endocrinology 72 377-382. (doi:10.1111/ j.1365-2265.2009.03667.x)

Ferrara N, Schweigerer L, Neufeld G, Mitchell R \& Gospodarowicz D 1987 Pituitary follicular cells produce basic fibroblast growth factor. PNAS 84 5773-5777. (doi:10.1073/pnas.84.16.5773)

Filippella M, Galland F, Kujas M, Young J, Faggiano A, Lombardi G, Colao A, Meduri G \& Chanson P 2006 Pituitary tumour transforming gene (PTTG) expression correlates with the proliferative activity and recurrence status of pituitary adenomas: a clinical and immunohistochemical study. Clinical Endocrinology 65 536-543. (doi:10.1111/j.1365-2265.2006.02630.x)

Frullanti E, Berking C, Harbeck N, Jézéquel P, Haugen A, Mawrin C, Parise O Jr, Sasaki H, Tsuchiya N \& Dragani TA 2011 Meta and pooled analyses of FGFR4 Gly388Arg polymorphism as a cancer prognostic factor. European Journal of Cancer Prevention 20 340-347. (doi:10.1097/CEJ.0b013e3283457274)

Giri D, Ropiquet F \& Ittmann M 1999 Alterations in expression of basic fibroblast growth factor (FGF) 2 and its receptor FGFR-1 in human prostate cancer. Clinical Cancer Research 5 1063-1071.

Givol D \& Yayon A 1992 Complexity of FGF receptors: genetic basis for structural diversity and functional specificity. FASEB Journal 6 3362-3369.

Gong J, Zhao Y, Abdel-Fattah R, Amos S, Xiao A, Lopes MB, Hussaini IM \& Laws ER 2008 Matrix metalloproteinase-9, a potential biological marker in invasive pituitary adenomas. Pituitary 11 37-48. (doi:10.1007/s11102-007-0066-2)

González-Arriaga P, Pascual T, García-Alvarez A, Fernández-Somoano A, López-Cima MF \& Tardón A 2012 Genetic polymorphisms in MMP 2, 9 and 3 genes modify lung cancer risk and survival. BMC Cancer 12 121. (doi:10.1186/1471-2407-12-121)

Gospodarowicz D, Ferrara N, Schweigerer L \& Neufeld G 1987 Structural characterization and biological functions of fibroblast growth factor. Endocrine Reviews 8 95-114. (doi:10.1210/edrv-8-2-95)

Henriksson ML, Edin S, Dahlin AM, Oldenborg PA, Öberg Å, Van Guelpen B, Rutegård J, Stenling R \& Palmqvist R 2011 Colorectal cancer cells activate adjacent fibroblasts resulting in FGF1/FGFR3 signaling and increased invasion. American Journal of Pathology 178 1387-1394. (doi:10.1016/j.ajpath.2010.12.008)

Hentschel SJ, McCutcheon E, Moore W \& Durity FA 2003 p53 and MIB-1 immunohistochemistry as predictors of the clinical behavior of nonfunctioning pituitary adenomas. Canadian Journal of Neurological Sciences 30 215-219.
Hunter JA, Skelly RH, Aylwin SJ, Geddes JF, Evanson J, Besser GM, Monson JP \& Burrin JM 2003 The relationship between pituitary tumour transforming gene (PTTG) expression and in vitro hormone and vascular endothelial growth factor (VEGF) secretion from human pituitary adenomas. European Journal of Endocrinology 148 203-211. (doi:10.1530/eje.0.1480203)

Hussaini IM, Trotter C, Zhao Y, Abdel-Fattah R, Amos S, Xiao A, Agi CU, Redpath GT, Fang Z, Leung GK et al. 2007 Matrix metalloproteinase-9 is differentially expressed in nonfunctioning invasive and noninvasive pituitary adenomas and increases invasion in human pituitary adenoma cell line. American Journal of Pathology 170 356-365. (doi:10.2353/ajpath.2007. 060736)

Ishikawa H, Heaney AP, Yu R, Horwitz GA \& Melmed S 2001 Human pituitary tumor-transforming gene induces angiogenesis. Journal of Clinical Endocrinology and Metabolism 86 867-874. (doi:10.1210/jc.86. 2.867)

Iuchi S, Saeki N, Uchino Y, Higuchi Y, Tatsuno I, Nakamura S, Yasuda T \& Yamaura A 2000 Cavernous sinus invasion and tumor proliferative potential of growth hormone-producing pituitary tumors. Endocrine Journal 47 (Suppl) S77-S79. (doi:10.1507/endocrj.47. SupplMarch_S77)

Jaakkola S, Salmikangas P, Nylund S, Partanen J, Armstrong E, Pyrhonen S, Lehtovirta P \& Nevanlinna H 1993 Amplification of fgfr4 gene in human breast and gynecological cancers. International Journal of Cancer 54 378-382. (doi:10.1002/ijc.2910540305)

Jaffrain-Rea ML, Di Stefano D, Minniti G, Esposito V, Bultrini A, Ferretti E, Santoro A, Faticanti Scucchi L, Gulino A \& Cantore G 2002 A critical reappraisal of MIB-1 labelling index significance in a large series of pituitary tumours: secreting versus non-secreting adenomas. Endocrine-Related Cancer 9 103-113. (doi:10.1677/ erc.0.0090103)

Kawamoto H, Kawamoto K, Mizoue T, Uozumi T, Arita K \& Kurisu K 1996 Matrix metalloproteinase-9 secretion by human pituitary adenomas detected by cell immunoblot analysis. Acta Neurochirurgica 138 1442-1448. (doi:10.1007/BF01411124)

Kiechle-Schwarz M, Bauknecht T, Wienker T, Walz L \& Pfleiderer A 1993 Loss of constitutional heterozygosity on chromosome 11p in human ovarian cancer. Positive correlation with grade of differentiation. Cancer 72 2423-2432. (doi:10.1002/10970142(19931015)72:8 <2423::AID-CNCR2820720821 > 3.0.CO;2-P)

Kitamura Y, Shimizu K, Tanaka S, Ito K \& Emi M 2000 Allelotyping of anaplastic thyroid carcinoma: frequent allelic losses on 1q, 9p, 11, 17, 19p, and 22q. Genes, Chromosomes E Cancer 27 244-251. (doi:10.1002/ (SICI) 1098-2264(200003) 27:3 < 244::AID-GCC4>3.0.CO;2-7)

Landolt AM, Shibata T \& Kleihues P 1987 Growth rate of human pituitary adenomas. Journal of Neurosurgery 67 803-806. (doi:10.3171/jns.1987.67.6.0803)

Lath R, Chacko G \& Chandy MJ 2001 Determination of Ki-67 labeling index in pituitary adenomas using MIB-1 monoclonal antibody. Neurology India 49 144-147.

Liu W, Matsumoto Y, Okada M, Miyake K, Kunishio K, Kawai N, Tamiya T \& Nagao S 2005 Matrix metalloproteinase 2 and 9 expression correlated with cavernous sinus invasion of pituitary adenomas. Journal of Medical Investigation 52 151-158. (doi:10.2152/jmi.52.151)

McCabe CJ, Boelaert K, Tannahill LA, Heaney AP, Stratford AL, Khaira JS, Hussain S, Sheppard MC, Franklyn JA \& Gittoes NJ 2002 Vascular endothelial growth factor, its receptor KDR/Flk-1, and pituitary tumor transforming gene in pituitary tumors. Journal of Clinical Endocrinology and Metabolism 87 4238-4244. (doi:10.1210/ jc.2002-020309)

Mete O \& Asa SL 2012 Clinicopathological correlations in pituitary adenomas. Brain Pathology 22 443-453. (doi:10.1111/j.1750-3639. 2012.00599.x)

Miyoshi A, Kitajima Y, Sumi K, Sato K, Hagiwara A, Koga Y \& Miyazaki K 2004 Snail and SIP1 increase cancer invasion by upregulating MMP family in hepatocellular carcinoma cells. British Journal of Cancer $\mathbf{9 0}$ 1265-1273. (doi:10.1038/sj.bjc.6601685) 
Morimoto Y, Ozaki T, Ouchida M, Umehara N, Ohata N, Yoshida A, Shimizu K \& Inoue H 2003 Single nucleotide polymorphism in fibroblast growth factor receptor 4 at codon 388 is associated with prognosis in high-grade soft tissue sarcoma. Cancer 98 2245-2250. (doi:10.1002/cncr.11778)

Morita K, Takano K, Yasufuku-Takano J, Yamada S, Teramoto A, Takei M, Osamura RY, Sano T \& Fujita T 2008 Expression of pituitary tumour-derived, N-terminally truncated isoform of fibroblast growth factor receptor 4 (ptd-FGFR4) correlates with tumour invasiveness but not with G-protein $\alpha$ subunit (gsp) mutation in human GH-secreting pituitary adenomas. Clinical Endocrinology 68 435-441. (doi:10.1111/j.1365-2265.2007.03062.x)

Morrison RS, Yamaguchi F, Bruner JM, Tang M, McKeehan W \& Berger MS 1994 Fibroblast growth factor receptor gene expression and immunoreactivity are elevated in human glioblastoma multiforme. Cancer Research 54 2794-2799.

Nasr HB, Mestiri S, Chahed K, Bouaouina N, Gabbouj S, Jalbout M \& Chouchane L 2007 Matrix metalloproteinase-1 (-1607) 1G/2G and $-9(-1562) \mathrm{C} / \mathrm{T}$ promoter polymorphisms: susceptibility and prognostic implications in nasopharyngeal carcinomas. Clinica Chimica Acta 384 57-63. (doi:10.1016/j.cca.2007.05.018)

Newey PJ \& Thakker RV 2011 Role of multiple endocrine neoplasia type 1 mutational analysis in clinical practice. Endocrine Practice $\mathbf{1 7}$ (Suppl 3) 8-17. (doi:10.4158/EP10379.RA)

Nishizawa R, Nagata M, Noman AA, Kitamura N, Fujita H, Hoshina H, Kubota T, Itagaki M, Shingaki S, Ohnishi M et al. 2007 The 2G allele of promoter region of matrix metalloproteinase- 1 as an essential pre-condition for the early onset of oral squamous cell carcinoma. BMC Cancer 7 187. (doi:10.1186/1471-2407-7-187)

Ohta T, Yamamoto M, Numata M, Iseki S, Tsukioka Y, Miyashita T, Kayahara M, Nagakawa T, Miyazaki I, Nishikawa K et al. 1995 Expression of basic fibroblast growth factor and its receptor in human pancreatic carcinomas. British Journal of Cancer 72 824-831. (doi:10.1038/bjc.1995.420)

Ota I, Li XY, Hu Y \& Weiss SJ 2009 Induction of a MT1-MMP and MT2MMP dependent basement membrane transmigration program in cancer cells by Snaill. PNAS 106 20318-20323. (doi:10.1073/pnas. 0910962106)

Ozer E, Canda MS, Ulukus C, Guray M \& Erbayraktar S 2003 Expression of Bcl-2, Bax and p53 proteins in pituitary adenomas: an immunohistochemical study. Tumori 89 54-59.

Pack SD, Kirschner LS, Pak E, Zhuang Z, Carney JA \& Stratakis CA 2000 Genetic and histologic studies of somatomammotropic pituitary tumors in patients with the "complex of spotty skin pigmentation, myxomas, endocrine overactivity and schwannomas" (Carney complex). Journal of Clinical Endocrinology and Metabolism 85 3860-3865. (doi:10.1210/jc.85.10.3860)

Pack SD, Qin LX, Pak E, Wang Y, Ault DO, Mannan P, Jaikumar S, Stratakis CA, Oldfield EH, Zhuang Z et al. 2005 Common genetic changes in hereditary and sporadic pituitary adenomas detected by comparative genomic hybridization. Genes, Chromosomes E Cancer 43 72-82. (doi:10.1002/gcc.20162)

Paek KI, Kim SH, Song SH, Choi SW, Koh HS, Youm JY \& Kim Y 2005 Clinical significance of Ki-67 labeling index in pituitary macroadenoma. Journal of Korean Medical Science 20 489-494. (doi:10.3346/jkms.2005.20.3.489)

Paez-Pereda M, Kuchenbauer F, Arzt E \& Stalla GK 2005 Regulation of pituitary hormones and cell proliferation by components of the extracellular matrix. Brazilian Journal of Medical and Biological Research 38 1487-1494. (doi:10.1590/S0100-879X2005001000005)

Page-McCaw A, Ewald AJ \& Werb Z 2007 Matrix metalloproteinases and the regulation of tissue remodelling. Nature Reviews. Molecular Cell Biology 8 221-233. (doi:10.1038/nrm2125)

Pan LX, Chen ZP, Liu YS \& Zhao JH 2005 Magnetic resonance imaging and biological markers in pituitary adenomas with invasion of the cavernous sinus space. Journal of Neuro-Oncology 74 71-76. (doi:10.1007/s11060-004-6150-9)
Pei L \& Melmed S 1997 Isolation and characterization of a pituitary tumor-transforming gene (PTTG). Molecular Endocrinology 11 433-441. (doi:10.1210/me.11.4.433)

Pizarro CB, Oliveira MC, Coutinho LB \& Ferreira NP 2004 Measurement of Ki-67 antigen in 159 pituitary adenomas using the MIB-1 monoclonal antibody. Brazilian Journal of Medical and Biological Research 37 235-243. (doi:10.1590/S0100879X2004000200011)

Putzolu M, Meloni A, Loche S, Pischedda C, Cao A \& Moi P 1997 A homozygous nonsense mutation of the human growth hormone receptor gene in a Sardinian boy with Laron-type dwarfism. Journal of Endocrinological Investigation 20 286-288.

Qian ZR, Sano T, Asa SL, Yamada S, Horiguchi H, Tashiro T, Li CC, Hirokawa M, Kovacs K \& Ezzat S 2004 Cytoplasmic expression of fibroblast growth factor receptor-4 in human pituitary adenomas: relation to tumor type, size, proliferation, and invasiveness. Journal of Clinical Endocrinology and Metabolism 89 1904-1911. (doi:10.1210/jc.2003-031489)

Qian ZR, Asa SL, Siomi H, Siomi MC, Yoshimoto K, Yamada S, Wang EL, Rahman MM, Inoue H, Itakura M et al. 2009 Overexpression of HMGA2 relates to reduction of the let-7 and its relationship to clinicopathological features in pituitary adenomas. Modern Pathology 22 431-441. (doi:10.1038/modpathol. 2008.202)

Raverot G, Wierinckx A, Dantony E, Auger C, Chapas G, Villeneuve L, Brue T, Figarella-Branger D, Roy P, Jouanneau E et al. 2010 Prognostic factors in prolactin pituitary tumors: clinical, histological, and molecular data from a series of 94 patients with a long postoperative follow-up. Journal of Clinical Endocrinology and Metabolism 95 1708-1716. (doi:10.1210/jc.2009-1191)

Rowe RG \& Weiss SJ 2009 Navigating ECM barriers at the invasive front: the cancer cell-stroma interface. Annual Review of Cell and Developmental Biology 25 567-595. (doi:10.1146/annurev.cellbio.24. 110707.175315)

Rutter JL, Mitchell TI, Buttice G, Meyers J, Gusella JF, Ozelius LJ \& Brinckerhoff CE 1998 A single nucleotide polymorphism in the matrix metalloproteinase-1 promoter creates an Ets binding site and augments transcription. Cancer Research 58 5321-5325.

Salehi F, Kovacs K, Scheithauer BW, Lloyd RV \& Cusimano M 2008 Pituitary tumor-transforming gene in endocrine and other neoplasms: a review and update. Endocrine-Related Cancer 15 721-743. (doi:10.1677/ERC-08-0012)

Salehi F, Agur A, Scheithauer BW, Kovacs K, Lloyd RV \& Cusimano M 2009 Ki-67 in pituitary neoplasms: a review-part I. Neurosurgery 65 429-437. (doi:10.1227/01.NEU.0000349930.66434.82)

Salehi F, Agur A, Scheithauer BW, Kovacs K, Lloyd RV \& Cusimano M 2010 Biomarkers of pituitary neoplasms: a review (Part II). Neurosurgery 67 1790-1798. (doi:10.1227/NEU.0b013e3181faa680)

Scheithauer BW, Gaffey TA, Lloyd RV, Sebo TJ, Kovacs KT, Horvath E, Yapicier O, Young WF Jr, Meyer FB, Kuroki T et al. 2006 Pathobiology of pituitary adenomas and carcinomas. Neurosurgery 59 341-353 (discussion 341-353). (doi:10.1227/01.NEU. 0000223437.51435.6E)

Sharrocks AD, Brown AL, Ling Y \& Yates PR 1997 The ETS domain transcription factor family. International Journal of Biochemistry $\mathcal{E}$ Cell Biology 29 1371-1387. (doi:10.1016/S1357-2725(97)00086-1)

Shevah O, Galli-Tsinopoulou A, Rubinstein M, Nousia-Arvanitakis S \& Laron Z 2004 Classical Laron syndrome in a girl with a heterozygous mutation and heterozygous polymorphism of the growth hormone receptor gene. Journal of Pediatric Endocrinology E Metabolism 17 371-374. (doi:10.1515/JPEM.2004.17.3.371)

Shimizu Y, Kondo S, Shirai A, Furukawa M \& Yoshizaki T 2008 A single nucleotide polymorphism in the matrix metalloproteinase- 1 and interleukin-gene promoter predicts poor prognosis in tongue cancer. Auris, Nasus, Larynx 35 381-389. (doi:10.1016/j.anl.2007. 12.002)

Shin EY, Lee BH, Yang JH, Shin KS, Lee GK, Yun HY, Song YJ, Park SC \& Kim EG 2000 Up-regulation and co-expression of fibroblast 
growth factor receptors in human gastric cancer. Journal of Cancer Research and Clinical Oncology 126 519-528. (doi:10.1007/ s004320000128)

Sivapragasam M, Rotondo F, Lloyd RV, Scheithauer BW, Cusimano M, Syro LV \& Kovacs K 2011 MicroRNAs in the human pituitary. Endocrine Pathology 22 134-143. (doi:10.1007/s12022-011-9167-6)

Stilling G, Sun Z, Zhang S, Jin L, Righi A, Kovacs G, Korbonits M, Scheithauer BW, Kovacs K \& Lloyd RV 2010 MicroRNA expression in ACTH-producing pituitary tumors: upregulation of microRNA-122 and -493 in pituitary carcinomas. Endocrine 38 67-75. (doi:10.1007/s12020-010-9346-0)

Sugiyama N, Varjosalo M, Meller P, Lohi J, Chan KM, Zhou Z, Alitalo K, Taipale J, Keski-Oja J \& Lehti K 2010 FGF receptor-4 (FGFR4) polymorphism acts as an activity switch of a membrane type 1 matrix metalloproteinase-FGFR4 complex. PNAS 107 15786-15791. (doi:10.1073/pnas.0914459107)

Suliman M, Royds J, Cullen D, Timperley W, Powell T, Battersby R \& Jones TH $2001 \mathrm{Mdm} 2$ and the p53 pathway in human pituitary adenomas. Clinical Endocrinology 54 317-325. (doi:10.1046/j.13652265.2001.01195.x)

Tahir A, Chahal HS \& Korbonits M 2010 Molecular genetics of the aip gene in familial pituitary tumorigenesis. Progress in Brain Research 182 229-253.

Tateno T, Asa SL, Zheng L, Mayr T, Ullrich A \& Ezzat S 2011 The FGFR4-G388R polymorphism promotes mitochondrial STAT3 serine phosphorylation to facilitate pituitary growth hormone cell tumorigenesis. PLoS Genetics 7 e1002400. (doi:10.1371/journal. pgen.1002400)

Thapar K, Kovacs K, Scheithauer BW, Stefaneanu L, Horvath E, Pernicone PJ, Murray D \& Laws ER Jr 1996a Proliferative activity and invasiveness among pituitary adenomas and carcinomas: an analysis using the MIB-1 antibody. Neurosurgery 38 99-106 (discussion 106-7). (doi:10.1097/00006123-199601000-00024)

Thapar K, Scheithauer BW, Kovacs K, Pernicone PJ \& Laws ER Jr $1996 b$ p53 expression in pituitary adenomas and carcinomas: correlation with invasiveness and tumor growth fractions. Neurosurgery 38 765-770. (doi:10.1227/00006123-199604000-00027)

Voorter CE, Ummelen MI, Ramaekers FS \& Hopman AH 1996 Loss of chromosome 11 and $11 \mathrm{p} / \mathrm{q}$ imbalances in bladder cancer detected by fluorescence in situ hybridization. International Journal of Cancer 65 301-307. (doi:10.1002/(SICI) 1097-0215 (19960126)65:3< 301::AID-IJC4>3.0.CO;2-3)

Wang F, Shu K, Lei T \& Xue D 2008 The expression of integrin- $\beta 1$ and FAK in pituitary adenomas and their correlation with invasiveness. Journal of Huazhong University of Science and Technology. Medical Sciences 28 572-575. (doi:10.1007/s11596-008-0518-6)

Wasylyk C, Gutman A, Nicholson R \& Wasylyk B 1991 The c-Ets oncoprotein activates the stromelysin promoter through the same elements as several non-nuclear oncoproteins. EMBO Journal 10 $1127-1134$.

Weil RJ, Vortmeyer AO, Huang S, Boni R, Lubensky IA, Pack S, Marx SJ, Zhuang Z \& Oldfield EH 1998 11q13 allelic loss in pituitary tumors in patients with multiple endocrine neoplasia syndrome type 1. Clinical Cancer Research 4 1673-1678.

Westermarck J, Seth A \& Kahari VM 1997 Differential regulation of interstitial collagenase (MMP-1) gene expression by ETS transcription factors. Oncogene 14 2651-2660. (doi:10.1038/sj.onc. 1201111)

Wierinckx A, Auger C, Devauchelle P, Reynaud A, Chevallier P, Jan M, Perrin G, Fèvre-Montange M, Rey C, Figarella-Branger D et al. 2007
A diagnostic marker set for invasion, proliferation, and aggressiveness of prolactin pituitary tumors. Endocrine-Related Cancer 14 887-900. (doi:10.1677/ERC-07-0062)

Wierinckx A, Roche M, Raverot G, Legras-Lachuer C, Croze S, Nazaret N, Rey C, Auger C, Jouanneau E, Chanson P et al. 2011 Integrated genomic profiling identifies loss of chromosome 11p impacting transcriptomic activity in aggressive pituitary PRL tumors. Brain Pathology 21 533-543.

Wolfsberger S, Wunderer J, Zachenhofer I, Czech T, Böcher-Schwarz HG, Hainfellner J \& Knosp E 2004 Expression of cell proliferation markers in pituitary adenomas - correlation and clinical relevance of MIB-1 and anti-topoisomerase-II $\alpha$. Acta Neurochirurgica 146 831-839.

Woo M, Park K, Nam J \& Kim JC 2007 Clinical implications of matrix metalloproteinase-1, $-3,-7,-9,-12$, and plasminogen activator inhibitor-1 gene polymorphisms in colorectal cancer. Journal of Gastroenterology and Hepatology 22 1064-1070. (doi:10.1111/j.14401746.2006.04424.x)

Yamada SM, Yamada S, Hayashi Y, Takahashi H, Teramoto A \& Matsumoto K 2002 Fibroblast growth factor receptor (FGFR) 4 correlated with the malignancy of human astrocytomas. Neurological Research 24 244-248. (doi:10.1179/016164102101199864)

Yonezawa K, Tamaki N \& Kokunai T 1997 Clinical features and growth fractions of pituitary adenomas. Surgical Neurology 48 494-500. (doi:10.1016/S0090-3019(97)00102-X)

Yoshimura N, Sano H, Hashiramoto A, Yamada R, Nakajima H, Kondo M \& Oka T 1998 The expression and localization of fibroblast growth factor-1 (FGF-1) and FGF receptor-1 (FGFR-1) in human breast cancer. Clinical Immunology and Immunopathology 89 28-34. (doi:10.1006/clin.1998.4551)

Yu S, Asa SL \& Ezzat S 2002 Fibroblast growth factor receptor 4 is a target for the zinc-finger transcription factor Ikaros in the pituitary. Molecular Endocrinology 16 1069-1078. (doi:10.1210/me.16.5.1069)

Yu S, Asa SL, Weigel RJ \& Ezzat S 2003 Pituitary tumor AP-2 $\alpha$ recognizes a cryptic promoter in intron 4 of fibroblast growth factor receptor 4. Journal of Biological Chemistry 278 19597-19602. (doi:10.1074/jbc.M212432200)

Zhang X, Horwitz GA, Heaney AP, Nakashima M, Prezant TR, Bronstein MD \& Melmed S 1999 Pituitary tumor transforming gene (PTTG) expression in pituitary adenomas. Journal of Clinical Endocrinology and Metabolism 84 761-767. (doi:10.1210/jc.84.2.761)

Zhao D, Tomono Y \& Nose T 1999 Expression of P27kipl and Ki-67 in pituitary adenomas: an investigation of marker of adenoma invasiveness. Acta Neurochirurgica 141 187-192. (doi:10.1007/ s007010050285)

Zhu X, Asa SL \& Ezzat S 2008 Fibroblast growth factor 2 and estrogen control the balance of histone 3 modifications targeting MAGE-A3 in pituitary neoplasia. Clinical Cancer Research 14 1984-1996. (doi:10.1158/1078-0432.CCR-07-2003)

Zou H, McGarry TJ, Bernal T \& Kirschner MW 1999 Identification of a vertebrate sister-chromatid separation inhibitor involved in transformation and tumorigenesis. Science 285 418-422. (doi:10.1126/science.285.5426.418)

Received in final form 12 July 2012

Accepted 19 July 2012

Made available online as an Accepted Preprint 19 July 2012 